\title{
Frequency of Toxoplasmosis among Zagazig University Students in 2017
}

\author{
Nahla Elsayed Elgammal ${ }^{1}$, Ahmed Mohammed Gaballah ${ }^{2}$ \\ , Naglaa Abd Al moneem Abd Al wahab, ${ }^{1}$ Esraa Fathallah Soliman ${ }^{1}$, \\ ${ }^{1}$ Department of Tropical Medicine, Faculty of Medicine, Zagazig University, Egypt. \\ ${ }^{2}$ Department of Clinical Pathology, Faculty of Medicine, Zagazig University, Egypt.
}

Corresponding Author Soliman, Esraa fathallah

Mobile:

$+201116530911$

E mail:

esraa.solimandr@gmai l.com

Key words:

Toxoplasmosis, students, seroprevalence , $\operatorname{Ig} G$
Background and study aim: Toxoplasmosis caused by Toxoplasma gondii, is a major health problem in which about $30 \%$ of people are born with anti Toxoplasma antibodies worldwide. Toxoplasmosis causes congenital infection, neurological and psychatric disorders. The present study aimed to determine prevalence and factors associated with $T$. gondii infection in Zagazig university students in 2017-2018.

Subjects and Methods: Through a crosssectional study, This study was done in Tropical Medicine Outpatient Clinic and Clinical Pathology Department of Zagazig University Hospitals, and including 159 healthy students coming to do clinical and laboratory evaluation before university attendance at student year 2017-2018. Serum samples were collected and tested for IgG antibodies against $T$. gondii using ELISA method.

\section{INTRODUCTION}

Toxoplasma gondii (T.gondii) is a crucial intracellular protozoan parasite widely prevalent in humans and animals, throughout the planet [1] .It may be a specific parasite of the host (usually cats and other members of the Felidae family) but features a broad range of intermediate hosts, including humans and a number of other wild and livestock. The life cycle of T.gondii consists of three infective stages: oocysts which are present only in cat feces, tachyzoites present within the host during the acute stage of infection, and bradyzoites that are found in tissue cysts [2].

T.gondii is transmitted to humans either congenitally, or via ingestion of
Results: In this study 159 healthy students are examined for antitoxoplasma IgG, 68 males (42.8\%) and 91 females (57.2\%). 65 students have Positive $\operatorname{IgG}(40.9 \%), 25.2 \%$ (N: 40$)$ of them showing high titre more than 300 and $15.7 \%(\mathrm{~N}: 25)$ of them showing titre low than 300 . The percentage of students have no infection is $59.1 \%$ (N: 94). There was a significant association between T.gondii seropositivity and age $(\mathrm{p}=0.007)$, dealing with animals $(p=0.001)$ eating fast food $(\mathrm{p}=0.002)$ and drinking non boiled milk $(\mathrm{p}=0.001)$.

Conclusion: Toxoplasmosis is present in healthy students. Infection is more prevalent in rural areas due to lack of health education and more dealing with animals. Dealing with animals, eating fast foods and drinking non boiled milk are considered a major risk factor for T.gondii infection. under cooked or raw meat from infected animals, or ingestion of food or water contaminated with oocysts excreted by infected fields. It has been found that about $50 \%$ of human cases are meat born. [3].

The importance of domestic chickens (Gallus domesticus) in transmission of T. gondii was studied only in a few studies in Egypt. Poultry meat is a part of food, consumed widely all over the world; therefore, eating uncooked or not properly cooked poultry meat may have a risk factor for $T$. gondii infection in humans or animals $[4,5]$. If we consider the most common food borne pathogens, human toxoplasmosis is considered second cause of death in Western countries.[6]. 


\section{SUBJECTS AND METHOD}

This observational cross sectional study was done in Tropical Medicine Outpatient Clinic and Clinical Pathology Department of Zagazig University Hospital, and including 159 healthy students coming to do clinical and laboratory evaluation before university attendance at student year 2017-2018.Informed consent was taken from all participants in the study and IRP approval was taken. We exclude students with history of chronic disease as diabetes, chronic renal or liver failure or malignancy.

All participants were subjected to the following: Full medical history with stress on socio demographic characteristics, eating habits; questionnaire is fulfilled by the students including (name, age, residence, marriage, dealing with animals and type of animals (including cats ,dogs, dogs\& cats, poultry and cows), eating fast food and type of food (such as : burger, beef, lunchon, uncooked meat),drinking non boiled milk, dealing with soil and blood transfusion), thorough clinical examination (general and local) especially lymph node examination, laboratory investigation: $\mathrm{CBC}$, $\mathrm{HCV} \mathrm{Ab}$ and (Anti toxoplasma IgG) using ELIZA technique.

$3 \mathrm{ml}$ venous blood was taken from every student in plain vacuum tube to clot for 20 minutes at $37 \mathrm{c}$ then centrifuged for 5 minutes on $3000 \mathrm{rpm}$, sera were separated and stored at $-20 \mathrm{c}$ till used and sandwich principle was used in technique. Results are determined via a calibration curve which is instrument specifically generated by 2 point calibration and a master curve provided via the reagent barcode.

Toxo $\operatorname{IgG}$ testing is used as first line screening assay and considered nonreactive if $<1 \mathrm{IU} / \mathrm{mL}$, indeterminate if $\geq 1:<3 \mathrm{IU} / \mathrm{mL}$ and reactive if $\geq 3 \mathrm{IU} / \mathrm{mL}$. A negative test result does not completely rule out infection with $T$. gondii. People may not exhibit any detectable IgG antibodies at the early stage of acute infection. The detection of Toxoplasma specific IgG antibodies in a single sample indicates a previous exposure to $T$. gondii but is not sufficient to distinguish between an acute or latent infection (irrespective of the level of the IgG antibody titer).

Measuring range from $0.13-650 \mathrm{IU} / \mathrm{mL}$ (defined by the lower detection limit and the maximum of the master curve). Values below the lower detection limit are reported as $<0.13 \mathrm{IU} / \mathrm{mL}$. Values above the measuring range are reported as $>650 \mathrm{IU} / \mathrm{mL}$ (or up to $13000 \mathrm{IU} / \mathrm{mL}$ for 20 fold diluted samples).Samples with values above the measuring range can be diluted with Diluents' Universal.

\section{RESULTS}

Table (1) shows: Toxoplasmosis infection among the studied subjects using IgG titre. The mean titre is 138.26+_215.05 with a range of (.13650).65 students have positive $\operatorname{IgG}(40.9 \%)$, $25.2 \%(\mathrm{~N}: 40)$ of them showing high titre more than 300 and $15.7 \%(\mathrm{~N}: 25)$ of them showing titre lower than 300 . The percentage of students have no infection is $59.1 \%(\mathrm{~N}: 94)$.

Table (2) shows: Toxoplasmosis infection among the studied subjects using IgG titre. The mean titre is 138.26+_215.05.65 students have Positive IgG (40.9\%), 25.2\% (N: 40) of them showing high titre more than 300 and $15.7 \%(\mathrm{~N}: 25)$ of them showing titre low than 300 . The percentage of students have no infection is $59.1 \%$ (N: 94).Comparison between negative and positive anti- toxoplasma $\operatorname{IgG}$ titre (either less than or more than 300) as regarding to demographic data. There is significant difference result as regarding age $(\mathrm{P}$ value $=.024)$, but no significant difference as regarding residence and marital status, $\mathrm{P}$ value $=(0.050) \&(0.965)$ respectively.

Table (3) shows: Comparison between negative anti-Toxoplasmosis IgG, positive antiToxoplasmosis IgG titre (less than 300 and more than 300) as regard dealing with animals. There is high significance in students dealing with animals as regarding IgG titre as 92 students (57.9\%) are dealing with animals, $24(26.1 \%)$ are positive (titre $<300)$, and $37(40.2 \%)$ of them are positive (titre $>300), \mathrm{P}$ value $=(<0.001)$. There is significant difference result in dealing with cats, but no significant difference in dealing with dogs, cows, poultry and soil.

Table (4) shows: Comparison between negative anti-Toxoplasmosis IgG, positive antiToxoplasmosis IgG titre (less than 300 and more than 300) as regard fast food eating. There is significant difference in students eating fast food as regarding titre as there is $142(89.3 \%)$ students are eating fast food,25 (17.6\%) of them are positive (titre<300).and $39(27.5 \%)$ of them are positive (titre>300). $\mathrm{P}$ value $=(0.008)$. There is high significant difference in students drinking non boiled milk, 13(8.2\%) students are drinking non boiled milk, $3(23.1 \%)$ of them are positive (titre $<300)$, and $10(76.9 \%)$ of them are positive (titre $>300), \mathrm{P}$ value $=(<0.001)$ 
Table (1): Toxoplasmosis infection among the studied subjects $(\mathrm{N}=159)$.

\begin{tabular}{|c|c|c|}
\hline \multirow[t]{2}{*}{ Toxoplasmosis infection } & \multicolumn{2}{|c|}{$\begin{array}{l}\text { The studied subjects } \\
(\mathrm{N}=159)\end{array}$} \\
\hline & No. & $\%$ \\
\hline \multicolumn{3}{|l|}{ Toxoplasmosis IgG Titre } \\
\hline Mean \pm SD & \multirow{2}{*}{\multicolumn{2}{|c|}{$\begin{array}{c}138.26 \pm 215.05 \\
325.065(0.13-650)\end{array}$}} \\
\hline Median (Range) & & \\
\hline Negative & 94 & $59.1 \%$ \\
\hline Positive & 65 & $40.9 \%$ \\
\hline$<300$ & 25 & $15.7 \%$ \\
\hline$>300$ & 40 & $25.2 \%$ \\
\hline
\end{tabular}

Table (2): Comparison between negative anti-Toxoplasmosis IgG, positive anti-Toxoplasma IgG titre (either less than 300 and more than 300) as regard demographic data.

\begin{tabular}{|c|c|c|c|c|c|c|c|c|c|c|}
\hline \multirow{3}{*}{$\begin{array}{c}\text { Demographic } \\
\text { Data }\end{array}$} & \multirow{2}{*}{\multicolumn{2}{|c|}{$\begin{array}{c}\text { All } \\
(\mathbf{N}=159)\end{array}$}} & \multicolumn{6}{|c|}{ Anti-Toxoplasmosis IgG (mean titre138.26 \pm 215.05} & \multirow[t]{3}{*}{ Test } & \multirow{3}{*}{$\begin{array}{c}\text { p-value } \\
\text { (Sig.) }\end{array}$} \\
\hline & & & \multicolumn{2}{|c|}{$\begin{array}{c}\text { Negative } \\
(\mathrm{N}=94)(59.1 \%)\end{array}$} & \multicolumn{2}{|c|}{$\begin{array}{c}\text { Positive }<300 \\
(\mathrm{~N}=25)(15.7 \%)\end{array}$} & \multicolumn{2}{|c|}{$\begin{array}{c}\text { Positive }>300 \\
(\mathrm{~N}=40)(25.2 \%)\end{array}$} & & \\
\hline & No. & $\%$ & No. & $\%$ & No. & $\%$ & No. & $\%$ & & \\
\hline \multicolumn{11}{|l|}{ Sex } \\
\hline Male & 68 & $42.8 \%$ & 45 & $66.2 \%$ & 9 & $13.2 \%$ & 14 & $20.6 \%$ & \multirow[t]{2}{*}{2.455} & 0.293 \\
\hline Female & 91 & $57.2 \%$ & 49 & $53.8 \%$ & 16 & $17.6 \%$ & 26 & $28.6 \%$ & & (NS) \\
\hline \multicolumn{11}{|l|}{ Age (days) } \\
\hline Mean \pm SD & \multirow{2}{*}{\multicolumn{2}{|c|}{$\begin{array}{c}19.81 \pm 0.40 \\
20 \\
(18-21)\end{array}$}} & \multirow{2}{*}{\multicolumn{2}{|c|}{$\begin{array}{c}19.73 \pm 0.44 \\
20 \\
(19-21)\end{array}$}} & \multirow{2}{*}{\multicolumn{2}{|c|}{$\begin{array}{c}19.90 \pm 0.27 \\
20 \\
(19-21)\end{array}$}} & 19.9 & \pm 0.34 & \multirow[t]{2}{*}{8.112} & \multirow{2}{*}{$\begin{array}{c}\mathbf{0 . 0 1 7} \\
\text { (S) }\end{array}$} \\
\hline Median (Range) & & & & & & & & $\begin{array}{l}20 \\
-21)\end{array}$ & & \\
\hline$\geq 20$ years & 31 & $19.5 \%$ & 25 & $80.6 \%$ & 2 & $6.5 \%$ & 4 & $12.9 \%$ & 7.422 & 0.024 \\
\hline$<20$ years & 128 & $80.5 \%$ & 69 & $53.9 \%$ & 23 & $18 \%$ & 36 & $28.1 \%$ & & (S) \\
\hline \multicolumn{11}{|l|}{ Residence } \\
\hline Urban & 80 & $50.3 \%$ & 52 & $65 \%$ & 7 & $8.8 \%$ & 21 & $26.2 \%$ & \multirow[t]{2}{*}{5.998} & \multirow{2}{*}{$\begin{array}{c}0.050 \\
(\mathrm{NS})\end{array}$} \\
\hline Rural & 79 & $49.7 \%$ & 42 & $53.2 \%$ & 18 & $22.8 \%$ & 19 & $24.1 \%$ & & \\
\hline \multicolumn{11}{|l|}{ Marital status } \\
\hline Unmarried & 151 & $95 \%$ & 89 & $58.9 \%$ & 24 & $15.9 \%$ & 38 & $25.2 \%$ & \multirow[t]{2}{*}{0.072} & \multirow{2}{*}{$\begin{array}{l}0.965 \\
\text { (NS) } \\
\end{array}$} \\
\hline Married & 8 & $5 \%$ & 5 & $62.5 \%$ & 1 & $12.5 \%$ & 2 & $25 \%$ & & \\
\hline
\end{tabular}

Kruskal Wallis H test.

Chi-square test.

$\mathrm{p}<0.05$ is significant. 
Table (3): Comparison between negative anti-Toxoplasmosis IgG, positive anti-Toxoplasma IgG titre ( less than 300 and more than 300) as regard dealing with animals.

\begin{tabular}{|c|c|c|c|c|c|c|c|c|c|c|}
\hline \multirow{3}{*}{$\begin{array}{l}\text { Dealing with } \\
\text { Animals \& soil }\end{array}$} & \multirow{2}{*}{\multicolumn{2}{|c|}{$\begin{array}{c}\text { All } \\
(\mathbf{N}=159)\end{array}$}} & \multicolumn{6}{|c|}{ Anti-Toxoplasmosis IgG } & \multirow[t]{3}{*}{ Test } & \multirow{3}{*}{$\begin{array}{c}\text { p-value } \\
\text { (Sig.) }\end{array}$} \\
\hline & & & \multicolumn{2}{|c|}{$\begin{array}{c}\text { Negative } \\
(\mathbf{N}=94)\end{array}$} & \multicolumn{2}{|c|}{$\begin{array}{c}\text { Positive }<300 \\
(N=25)\end{array}$} & \multicolumn{2}{|c|}{$\begin{array}{c}\text { Positive }>300 \\
(N=40)\end{array}$} & & \\
\hline & No. & $\%$ & No. & $\%$ & No. & $\%$ & No. & $\%$ & & \\
\hline \multicolumn{11}{|l|}{ Any animals } \\
\hline No & 67 & $42.1 \%$ & 46 & $68.7 \%$ & 7 & $10.4 \%$ & 14 & $20.9 \%$ & \multirow[t]{2}{*}{15.721} & \multirow{2}{*}{$\begin{array}{c}<0.001 \\
\text { (HS) }\end{array}$} \\
\hline Yes & 92 & $57.9 \%$ & 31 & $33.7 \%$ & 24 & $26.1 \%$ & 37 & $40.2 \%$ & & \\
\hline Cats & 19 & $11.95 \%$ & 7 & $36.8 \%$ & 5 & $26.3 \%$ & 7 & $36.8 \%$ & \multirow[t]{5}{*}{26.276} & \multirow{5}{*}{$\begin{array}{c}\mathbf{0 . 0 0 3} \\
(\mathrm{S})\end{array}$} \\
\hline Dogs & 5 & $3.15 \%$ & 4 & $80 \%$ & 0 & $0 \%$ & 1 & $20 \%$ & & \\
\hline Cats \& dogs & 26 & $16.4 \%$ & 3 & $11.5 \%$ & 13 & $50 \%$ & 10 & $38.5 \%$ & & \\
\hline Cows & 17 & $10.7 \%$ & 3 & $17.6 \%$ & 4 & $23.5 \%$ & 10 & $58.9 \%$ & & \\
\hline Poultry & 25 & $15.7 \%$ & 5 & $20 \%$ & 5 & $20 \%$ & 15 & $60 \%$ & & \\
\hline \multicolumn{11}{|l|}{ Cats } \\
\hline No & 114 & $71.7 \%$ & 74 & $64.9 \%$ & 14 & $12.3 \%$ & 26 & $22.8 \%$ & \multirow[t]{2}{*}{13.023} & \multirow{2}{*}{$\begin{array}{c}\mathbf{0 . 0 0 1} \\
(\mathbf{S}) \\
\end{array}$} \\
\hline Yes & 45 & $28.3 \%$ & 13 & $28.9 \%$ & 15 & $33.3 \%$ & 17 & $37.8 \%$ & & \\
\hline \multicolumn{11}{|l|}{$\overline{\text { Dogs }}$} \\
\hline No & 128 & $80.5 \%$ & 78 & $60.9 \%$ & 18 & $14.1 \%$ & 32 & $25 \%$ & \multirow[t]{2}{*}{3.238} & \multirow{2}{*}{$\begin{array}{c}0.198 \\
(\mathrm{NS})\end{array}$} \\
\hline Yes & 31 & $19.5 \%$ & 12 & $38.7 \%$ & 9 & $29 \%$ & 10 & $32.3 \%$ & & \\
\hline \multicolumn{11}{|l|}{ Cows } \\
\hline No & 142 & $89.3 \%$ & 86 & $60.6 \%$ & 22 & $15.5 \%$ & 34 & $23.9 \%$ & \multirow[t]{2}{*}{3.888} & \multirow{2}{*}{$\begin{array}{l}0.143 \\
(\mathrm{NS}) \\
\end{array}$} \\
\hline Yes & 17 & $10.7 \%$ & 3 & $17.6 \%$ & 4 & $23.5 \%$ & 10 & $58.9 \%$ & & \\
\hline \multicolumn{11}{|l|}{$\overline{\text { Poultry }}$} \\
\hline No & 134 & $84.3 \%$ & 81 & $60.5 \%$ & 24 & $15.6 \%$ & 37 & $24 \%$ & \multirow[t]{2}{*}{2.897} & \multirow{2}{*}{$\begin{array}{c}0.123 \\
(\mathrm{NS})\end{array}$} \\
\hline Yes & 25 & $15.7 \%$ & 5 & $20 \%$ & 5 & $20 \%$ & 15 & $60 \%$ & & \\
\hline \multicolumn{11}{|l|}{ Dealing with soil } \\
\hline No & 128 & $80.5 \%$ & 80 & $62.5 \%$ & 18 & $14.1 \%$ & 30 & $23.4 \%$ & \multirow[t]{2}{*}{3.192} & \multirow{2}{*}{$\begin{array}{c}0.203 \\
(\mathrm{NS})\end{array}$} \\
\hline Yes & 31 & $19.5 \%$ & 14 & $45.2 \%$ & 7 & $22.6 \%$ & 10 & $32.3 \%$ & & \\
\hline
\end{tabular}

Chi-square test.

$\mathrm{p}<0.05$ is significant.

Sig.: significance 
Table (4): Comparison between negative anti-Toxoplasmosis IgG, positive anti-Toxoplasmosis IgG titre (less than 300 and more than 300) as regard food borne.

\begin{tabular}{|c|c|c|c|c|c|c|c|c|c|c|}
\hline \multirow[t]{3}{*}{ Food borne exposure } & \multirow{2}{*}{\multicolumn{2}{|c|}{$\begin{array}{c}\text { All } \\
(\mathrm{N}=159)\end{array}$}} & \multicolumn{6}{|c|}{ Anti-Toxoplasmosis IgG } & \multirow[t]{3}{*}{ Test } & \multirow{3}{*}{$\begin{array}{l}\text { p-value } \\
\text { (Sig.) }\end{array}$} \\
\hline & & & \multicolumn{2}{|c|}{$\begin{array}{c}\text { Negative } \\
(\mathrm{N}=94)\end{array}$} & \multicolumn{2}{|c|}{$\begin{array}{c}\text { Positive }<300 \\
(\mathrm{~N}=25)\end{array}$} & \multicolumn{2}{|c|}{$\begin{array}{c}\text { Positive }>300 \\
(N=40)\end{array}$} & & \\
\hline & No. & $\%$ & No. & $\%$ & No. & $\%$ & No. & $\%$ & & \\
\hline \multicolumn{11}{|l|}{ Any fast food } \\
\hline No & 17 & $10.7 \%$ & 16 & $94.1 \%$ & 0 & $0 \%$ & 1 & $5.9 \%$ & \multirow[t]{2}{*}{9.748} & \multirow{2}{*}{$\begin{array}{c}\mathbf{0 . 0 0 8} \\
(\mathbf{S})\end{array}$} \\
\hline Yes & 142 & $89.3 \%$ & 78 & $54.9 \%$ & 25 & $17.6 \%$ & 39 & $27.5 \%$ & & \\
\hline Burger & 36 & $22.6 \%$ & 29 & $80.5 \%$ & 6 & $16.7 \%$ & 1 & $2.8 \%$ & \multirow[t]{7}{*}{$\mathbf{5 8 . 5 5 0}$} & \multirow{7}{*}{$\begin{array}{c}<0.001 \\
\text { (HS) }\end{array}$} \\
\hline Lunchon & 28 & $17.6 \%$ & 18 & $64.3 \%$ & 4 & $14.3 \%$ & 6 & $21.4 \%$ & & \\
\hline Beef & 10 & $6.3 \%$ & 7 & $70 \%$ & 2 & $20 \%$ & 1 & $10 \%$ & & \\
\hline Uncooked meat & 10 & $6.3 \%$ & 5 & $50 \%$ & 4 & $40 \%$ & 1 & $10 \%$ & & \\
\hline Burger \& Lunchon & 35 & $22 \%$ & 13 & $37.1 \%$ & 6 & $17.1 \%$ & 16 & $45.7 \%$ & & \\
\hline Burger \& Beef & 17 & $10.7 \%$ & 4 & $23.5 \%$ & 3 & $17.6 \%$ & 10 & $58.8 \%$ & & \\
\hline Lunchon \& Beef & 6 & $3.8 \%$ & 1 & $16.7 \%$ & 0 & $0 \%$ & 5 & $83.3 \%$ & & \\
\hline \multicolumn{11}{|l|}{ Burger } \\
\hline No & 70 & $44 \%$ & 48 & $68.6 \%$ & 10 & $14.3 \%$ & 12 & $17.1 \%$ & \multirow[t]{2}{*}{5.247} & \multirow{2}{*}{$\begin{array}{c}0.073 \\
(\mathrm{NS}) \\
\end{array}$} \\
\hline Yes & 89 & $56 \%$ & 46 & $51.7 \%$ & 15 & $16.8 \%$ & 28 & $31.5 \%$ & & \\
\hline \multicolumn{11}{|l|}{ Lunchon } \\
\hline No & 90 & $56.6 \%$ & 61 & $68.5 \%$ & 15 & $16.9 \%$ & 13 & $14.6 \%$ & \multirow[t]{2}{*}{12.143} & \multirow{2}{*}{$\begin{array}{c}\mathbf{0 . 0 0 2} \\
(\mathbf{S})\end{array}$} \\
\hline Yes & 69 & $43.4 \%$ & 32 & $46.4 \%$ & 10 & $14.3 \%$ & 27 & $38.6 \%$ & & \\
\hline \multicolumn{11}{|l|}{ Beef } \\
\hline No & 126 & $79.2 \%$ & 82 & $65.1 \%$ & 20 & $15.9 \%$ & 24 & $19 \%$ & \multirow[t]{2}{*}{12.664} & \multirow{2}{*}{$\begin{array}{c}\mathbf{0 . 0 0 2} \\
(\mathbf{S}) \\
\end{array}$} \\
\hline Yes & 33 & $20.8 \%$ & 12 & $36.4 \%$ & 5 & $15.2 \%$ & 16 & $48.5 \%$ & & \\
\hline \multicolumn{11}{|l|}{ Uncooked meat } \\
\hline No & 149 & $93.7 \%$ & 89 & $59.7 \%$ & 21 & $14.1 \%$ & 39 & $26.2 \%$ & \multirow[t]{2}{*}{5.125} & \multirow{2}{*}{$\begin{array}{c}0.077 \\
(\mathrm{NS}) \\
\end{array}$} \\
\hline Yes & 10 & $6.3 \%$ & 5 & $50 \%$ & 4 & $40 \%$ & 1 & $10 \%$ & & \\
\hline \multicolumn{11}{|c|}{ Drinking non-boiled milk } \\
\hline No & 146 & $91.8 \%$ & 94 & $64.4 \%$ & 22 & $15.1 \%$ & 30 & $20.5 \%$ & \multirow[t]{2}{*}{23.937} & \multirow{2}{*}{$\begin{array}{c}<0.001 \\
(\mathrm{HS})\end{array}$} \\
\hline Yes & 13 & $8.2 \%$ & 0 & $0 \%$ & 3 & $23.1 \%$ & 10 & $76.9 \%$ & & \\
\hline
\end{tabular}

Chi-square test.

$\mathrm{p}<0.05$ is significant.

Sig.: significance.

\section{DISCUSSION}

Toxoplasma gondii is an intracellular protozoan parasite highly prevalent in humans and animals, including poultry, in the world $[\mathbf{1 , 4}]$. It has been evaluated that about $30 \%$ of population has been infected with Toxoplasma gondii [2]. T. gondii is mostly transmitted to humans either congenitally, or via eating under cooked or raw meat of infected animals, or ingestion of food or water contaminated with oocysts excreted by infected animals [7].

The aim of this study is to evaluate the frequency of toxoplasma IgG among Zagazig University Students and to evaluate some sociodemographic factors, characteristic features and eating habits in toxoplasma cases. In this study 159 healthy students are examined for antitoxoplasma $\mathrm{IgG}, 68$ males $(42.8 \%)$ and 91 females $(57.2 \%)$. Mean age is $19.81 \pm 0.40$ with a range of (18-21). 80 are urban (50.3\%) and 79 are rural $(49.7 \%)$. (table 2 )

The overall seroprevalence of toxoplasma $\operatorname{IgG}$ in this study is (40.9\%) 65 students. 25 students (15.7\%) have IgG titre $<300$ and 40 students (25.2\%) have IgG titre $>300$ (Table 1).In comparison to previous studies conducted on healthy blood donors in Egypt, this rate of seroprevalence was lower than the prevalence in Alexandria Governorates (65.3\%) [8] and also lower than the study reported from Mansoura governorate, Egypt, in 2009, in which the prevalence of Toxoplasma-specific IgG in blood donors, was $59.6 \%$ [9]. The incidence in this study was higher than the $19.5 \%$ incidence reported much earlier in 1986 from Cairo [10].

When compared with different countries, the

Elgammal et al., Afro-Egypt J Infect Endem Dis 2020;10(2):120-128

https://aeji.journals.ekb.eg/

http://mis.zu.edu.eg/ajied/home.aspx 
recorded seropositivity was much higher than that reported in blood donors in Mexico (7.4\%) [11], Thailand (9\%) [12], Chile (21.2\%) [13], Malaysia (28.1\%) [14], Czech Republic (33.1\%) [15]. Although, seropositivity was lower than that reported in blood donors in Brazil (79.0\%) [16] and in Cuba (73.43\%), Mali (41.2\%) [17], and Saudi Arabia (52.1\%) [18].The variability in the prevalence levels of $T$. gondii infection among blood donor population may be attributed to the individual habits and characteristics of the populations.

In this study prevalence is higher in females $(46.2 \%)$ than in males (33.8\%) with no significant difference (Table 2). A similar finding was reported previously $[\mathbf{1 3 , 1 9 , 2 0 , 2 1 ]}$. Increasing of anti-T.gondii antibodies among female donors may be due to more exposure of females to oocysts and tissue cysts during their daily activities. In contrast, $T$. gondii seropositivity was significantly higher among male donors as detected by 22 . Sundar et al and Ormazdi et al[22,23].

As regarding age, the prevalence is higher in young age (46.1\% in age <20 years and $19.4 \%)$ in age $>=20$ years) with significant difference (Table 2). This may be due to more consumption of this age group to fast food. Such a finding was in contrary with those observed in other studies $[9,11,16]$ that showed increase in T.gondii prevalence in older age groups (35-45).

In this study seropositivity in rural areas (46.8\%) is higher than in urban areas (35\%).This finding is in agreement with El sheikha [9] and Mahmoud [21] who showed significant difference between rural and urban areas and may be due to low socioeconomic standards, lack of hand hygiene before meals, eating unwashed vegetables, drinking unfiltered water and frequent exposure to animal excreta.

As regarding dealing with animals, prevalence in students dealing with animals $(66.3 \%)$ is higher than those not dealing with animals $(31.3 \%)$ with high significant difference, especially those dealing with cats, cows and poultry (Table 3 ). This is in agreement with study done in Benisuef, Egypt which found a relation between toxoplasma infection and contact with chickens [24]. Also El sheikha and Alvarado-Esquivel found relation between toxoplasmosis and contact with cats $[\mathbf{1 1}, \mathbf{2 5}]$. However, in contrary to our study El-Deeb [26] found no significant correlation between seropositivity to toxoplasma antibodies and contact with domestic cats in Menoufia, Egypt. This may be attributed to prescence of pet cats and stray cats which are more exposed to parasites.

As regarding food-borne, prevalence of toxoplasmosis in students eating fast food (45.1\%) is higher than those not eating fast food (5.9\%) with high significant difference (Table 4) with high prevalence in eating more than one type of fast food ,this may be attributed to more exposure to cysts in undercooked or raw meat. Our study is in agreement with previous studies done by Mahmoud [21] and Excler [27]. Similarly, several studies have reported the foodborne transmission as a major infection route in blood donors $[23,29]$.

This study showed high prevalence of toxoplasmosis in students drinking non boiled milk or homemade cheese $(100 \%)$ with high significant difference (Table 4).The data suggest that drinking raw milk from infected animals might be another possible route for the transmission of T.gondii as was reported by Sacks [30]. This also in agreement with study done in pregnant women in Sharkia, Egypt that showed a correlation between raw milk and toxoplasmosis [31]. Similarly, El-Deeb [26] in Menoufia, Egypt, found significant correlation between raw milk consumption and T.gondii seroprevalence. In contrary, this finding was in contrast with other studies in USA [29], Ethiopia [32], Brazil [33] and Kyrgyz Republic [34] that reported no significant relation between raw milk consumption and $T$. gondii seroprevalence. This could be attributed to the habit in using raw milk for making cheese in the current study and hygienic measures and sanitation used in growing animals in developed countries.

As regarding dealing with soil, Prevalence in students dealing $(54.8 \%)$ is higher than those not dealing with soil $(37.5 \%)$, with no significant difference (Table 3).This finding corroborates with other studies in USA [29], Ethiopia [35] and Brazil [33,36].

As regarding anti-toxoplasmosis $\operatorname{IgG}$ titre, (13.2\%) of male cases had IgG titre less than $300 \mathrm{IU} / \mathrm{ml}$ and $(20.6 \%)$ of males had $\mathrm{IgG}$ titre more than $300 \mathrm{IU} / \mathrm{ml}$. Also,(17.6\%) of females showed IgG titre less than $300 \mathrm{IU} / \mathrm{ml}$ and $(28.6 \%)$ showed titre more than $300 \mathrm{IU} / \mathrm{ml}$. Also, $(28.1 \%)$ of subjects $<20$ years had positive $\mathrm{IgG}$ titre $>300 \mathrm{IU} / \mathrm{ml}$ and $18 \%$ had $\mathrm{IgG}$ titre $<300 \mathrm{IU} / \mathrm{ml}$. $26.2 \%$ of urban subjects showed 
IgG titre $>300 \mathrm{IU} / \mathrm{ml}$ and $24.1 \%$ of rural subjects had IgG titre $>300 \mathrm{IU} / \mathrm{ml}$ (Table 2).As regarding dealing with animals, $40.2 \%$ of the studied subjects had IgG titre $>300 \mathrm{IU} / \mathrm{ml}$ and were dealing with poultry, cows, cats and dogs (Table 3). As regarding fast food ,89.3\% of subjects were eating fast food and $27.5 \%$ of them showed anti- toxoplasma IgG titre $>300 \mathrm{IU} / \mathrm{ml}$ (Table 4). More studies are needed to validate various titres as a cut off value for diagnosis.

\section{CONCLUSION}

Toxoplasmosis is present in apparently healthy students. It is more prevalent in young age group. Infection is more prevalent in rural areas due to lack of health education and more dealing with animals. Dealing with animals, eating fast foods and drinking non boiled milk are considered a major risk factor for T.gondii infection. Eating fast food mainly Burger, Lunchon and uncooked meat are hidden sources for toxoplasma transmission. Increased consumption of fast food between students is a source of toxoplasma infection even without symptoms.

\section{Funding: None.}

Conflict of interest: Non declared.

Ethical consideration: the study design was revised and approved by the institutional review board in the Faculty of Medicine, Zagazig University.

\section{REFERENCES}

1. Zhou P, Chen Z, Li HL, Zheng H, He S, Lin RQ, et al. Toxoplasma gondii infection in humans in China. Parasites \& Vectors 2011; 4: 165.

2. Tenter AM, Heckeroth AR, Weiss LM. Toxoplasma gondii from animals to humans International Journal for Parasitology 2000; 30: 1217-1258.

3. Roghmann MC, Faulkner CT, Lefkowitz A, Patton S, Zimmerman J, Morris JG Jr. Decreased seroprevalence for Toxoplasma gondii in Seventh Day Adventists in Maryland. American Journal of Tropical Medicine and Hygiene 1999; 60(5):790-792.
4. Dubey JP. Toxoplasmosis of Animals and Humans. Secondth edition CRC Press. Boca Raton, New York Inc., 2010a pp: 1-313.

5. Dubey JP. Toxoplasma gondii infections in chickens (Gallus domesticus): prevalence, clinical disease, diagnosis and public health Zoonosis. Public Health 2010b; 57: 60-73.

6. Mangen MJ, Bouwknegt M, Friesema IH, Haagsma JA, Kortbeek LM, Tariq L, et al. Costof-illness and disease burden of food-related pathogens in the Netherlands. International Journal of Food Microbiology 2015; 196:84-93.

7. Tonouhewa ABN, Akpo Y, Sessou P, Adoligbe $\mathrm{C}$, Yessinou E, Hounmanou YG, et al. Toxoplasma gondii infection in meat animals from Africa: Systematic review and metaanalysis of sero-epidemiological studies, Veterinary World 2017; 10: 194-208

8. El-Geddawi OA, El-Sayad MH, Sadek NA, Hussien NA, Ahmed MA. Detection of T. gondii infection in blood donors in Alexandria, Egypt, using serological and molecular strategies. Parasitol United J 2016; 9: 24-30.

9. El sheikha H.M., Azab M.S., Abou samra N.K., Rahbar MH, El ghannam DM, Raafat D. Seroprevalence of and risk factors for Toxoplasma gondii antibodies among asymptomatic blood donors in Egypt. Parasitol Res 2009; 104(6): 1471-1476.

10. Azab ME, Safar EH, El-Shennawt SF, Hassan FA. Serological evidence of infection with Plasmodium and Toxoplasma in blood donors to Ain-Shams University Hospital. J Egypt Soc Parasitol 1986; 16:163-170.

11. Alvarado-Esquivel C, Mercado-Suarez MF, Rodríguez-Briones A, Fallad-Torres L, AyalaAyala JO, Nevarez-Piedra LJ, et al. Sero epidemiology of infection with Toxoplasma gondii in healthy blood donors of Durango, Mexico. BMC Infect Dis 2007; 7:75-81.

12. Pinlaor S, Ieamviteevanich $K$, Pinlaor $P$, Maleewong W. Seroprevalence of specific total immunoglobulin (Ig), $\mathrm{IgG}$ and $\mathrm{IgM}$ antibodies to Toxoplasma gondii in blood donors from Loei Province, Northeast Thailand. Southeast Asian J Trop Med Public Health 2000; 31:123-127.

13. Zamorano CG, Contreras MC, Villalobos S, Sandoval L, Salinas P. Sero epidemiological survey of human toxoplasmosis in Osorno, Region X, Chile, 1998. BolChilParasitol 1999; 54:33-36. 
14. Nissapatorn V, Kamarulzaman A, Init I, Tan LH, Rohela M, Norliza A, et al. Sero-epidemiology of toxoplasmosis among HIV-infected patients and healthy blood donors. Med J Malaysia 2002; 57: 304-310.

15. Svobodová V, Literák I. Prevalence of IgM and IgG antibodies to Toxoplasma gondii in blood donors in the Czech Republic. Eur J Epidemiol 1998; 14:803-805.

16. Coelho RA, Kobayashi M, Carvalho LB Jr. Prevalence of IgG antibodies specific to Toxoplasma gondii among blood donors in Recife, Northeast Brazil. Rev Inst Med Trop Sao Paulo 2003; 45: 229-231

17. Maïga I, Kiemtoré P, Tounkara A. Prevalence of anti Toxoplasma antibodies in patients with acquired immunodeficiency syndrome and blood donors in Bamako. Bull Soc Pathol Exot 2001; 94:268-270.

18. Al-Amari OM. Prevalence of antibodies to Toxoplasma gondii among blood donors in Abha, Asir Region, south-western Saudi Arabia. J Egypt Public Health Assoc 1994; 69:77-88.

19. Gongora-Biachi RA, Gonzalez-Martinez P, Castro-Sansores C, Alvarez-Moguel R. Antibodies against Toxoplasma gondii in patients with HIV in Yucatán. Rev Invest Clin 1998; 50:419-422.

20. Elhence P, Agarwal P, Prasad KN, Chaudhary RK. Seroprevalence of Toxoplasma gondii antibodies in North Indian blood donors: Implications for transfusion transmissible toxoplasmosis. Transfus Apher Sci 2010; 43(1): 37-40

21. Mahmoud V, Saedi Dezaki E, Soleimani S, Baneshi MR, Kheirandish F, Ezatpour B. Seroprevalence and risk factors of Toxoplasma gondii infection among healthy blood donors in southeast of Iran. Parasite Immunol 2015; 37(7), 362-367.

22. Sundar P, Mahadevan A, Jayshree RS, Subbakrishna DK, Shankar SK. Toxoplasma seroprevalence in healthy voluntary blood donors from urban Karnataka. Indian J Med Res 2007; 126(1: 50-56.

23. Ormazdi H, Sanikhani N, Hadighi R, Akhlaghi L, Memar AR, Razmju E. Investigation of antibodies (IgG and IgM) against Toxoplasma gondii in blood donors referred to Tehran blood transfusion organization by ELISA. Urmia Med J 2010; 21 (2): 212-216.
24. Aboelhadid SM, Ab del-Ghany AE, Ibrahim MA, Mahran HA. Department of Parasitology Fac. Vet. Med. Beni-Suef University, Egypt 2 Hygiene, Management and Zoonosis Department Fac. Vet. Med. Beni-Suef University, Egypt .Global Veterinaria 2013; 11 (2): 139-144.

25. El sheikha HM. Congenital toxoplasmosis: priorities for further health promotion action. Public Health 2008; 122: 335-35.

26. El Deeb HK, Salah-El din H, Khodeer S, Allah AA. Prevalence of toxoplasma gondii infection in antenatal population in Menoufia governorate, Egypt. Acta Trop 2012; 124(3):185-191.

27. Excler JL, Pretat E, Pozzetto B, Charpin B, Garin JP. Sero-epidemiological survey for toxoplasmosis in Burundi. Trop Med Parasitol 1988; 39: 139-141.

28. Baril L, Ancelle T, Goulet V, Thulliez P, TirardFleury V, Carme B. Risk factors for Toxoplasma infection in pregnancy: a case-control study in France. Scand J Infect Dis 1999; 31: 305-309.

29. Jones JL, Dargelas V, Roberts J, Press C, Remington JS, Montoya JG. Risk factors for toxoplasma gondii infection in the United States. Clin Infect Dis 2009; 49 (6): 878-884.

30. Sacks JJ, Roberto RR, Brooks NF. Toxoplasmosis infection associated with raw goats milk. JAMA 1982; 248.14:1728-1732.

31. Ahmed HA, Shafik SM, Ali MEM, El ghamry ST, Ahmed AA. Molecular detection of Toxoplasma gondii DNA in milk and risk factors analysis of seroprevalence in pregnant women at Sharkia, Egypt. Veterinary World 2014; 7 (8):594-600 .

32. Gebremedhin EZ, Abebe AH, Tessema TS, Tullu KD, Medhin G, Vitale M, et al. Sero epidemiology of toxoplasma gondii infection in women of child-bearing age in central Ethiopia. BMC Infect Dis 2013; 13: 101.

33. Moura FLD, Amendoeira MRR, Bastos OMP, Mattos DPBG, Fonseca ABM, Nicolau JL, et al. Prevalence and risk factors for toxoplasma gondii infection among pregnant and postpartum women attended at public healthcare facilities in the City of Niteroi, State of Rio de Janeiro, Brazil. Rev Soc Bras Med Trop 2013; 46: 200-207.

34. Minbaeva G, Schweiger A, Bodosheva A, Kuttubaev O, Hehl AB, Tanner I, et al. toxoplasma gondii infection in Kyrgyzstan: seroprevalence, risk factor analysis, and estimate of congenital and AIDS-related toxoplasmosis. PLoSNegl Trop Dis 2013; 7 (2): e2043. 
35. Zemene E, Yewhalaw D, Abera S, Belay T, Samuel A, Zeynudin A. Seroprevalence of toxoplasma gondii and associated risk factors among pregnant women in Jimma town, Southwestern Ethiopia. BMC Infect Dis 2012; 12 (1): 1-6.
36. Sroka S, Bartelheimer N, Winter A, Heukelbach J, Ariza L, Ribeiro $\mathrm{H}$, et al. Prevalence and risk factors of toxoplasmosis among pregnant women in Fortaleza, NorthEastern Brazil. Am J Trop Med Hyg 2010; 83 (3): 528-533. 